\title{
laborhiftórico
}

ISSN 2359-6910

https://revistas.ufrj.br/index.php/lh/

ARTIGO

Recebido em 31 de maio de 2020

Aprovado em 5 de agosto de 2020

\section{O método histórico-comparativo e a sua validade para o estudo da morfologia lexical: síntese de uma proposta de aplicação ao galego-português e ao castelhano}

The historical-comparative method and its validity for the study of lexical morphology: the synthesis of a application proposal to Galician-Portuguese and Castilian

DOI: https://doi.org/10.24206/lh.v6i3.35118

Mailson Lopes

Professor de Língua Espanhola da Universidade Federal da Bahia. Doutor em Língua e Cultura (Linguística Histórica) pela Universidade Federal da Bahia, em regime de cotutela com a Universidade de Coimbra. Dedica-se a investigações no âmbito da Linguística Histórica, com ênfase em Morfologia, Semântica e Lexicologia das línguas portuguesa, espanhola e galega, especialmente nos seguintes temas: formação de palavras (prefixação) e antroponímia. 


\title{
RESUMO
}

Este artigo elenca os principais postulados e alguns desenvolvimentos do método históricocomparativo aplicado às línguas românicas, desembocando no rastreamento de suas incursões ou lacunas na apreciação da morfologia lexical. Pari passu a isso, esquematiza os aspectos fundamentais de uma proposta de apreciação histórico-comparativa aplicada por Lopes (2018) à prefixação no galegoportuguês e no castelhano e que pode ser tomada como modelo básico preliminar para futuras aplicações panromânicas sobre outras operações da lexicogênese morfológica, como a sufixação, a composição e a parassíntese (e também a prefixação, com a inclusão de mais sistemas linguísticos, para além dos dois já perscrutados pelo mencionado morfólogo). Perpassa todo o texto a ideia de uma incontestável relevância e atualidade do método para o cotejo historicocêntrico entre línguas, desde que sob pautas renovadas, mediante revisões teórico-epistemológicas subsidiadas pelos avanços propiciados pelas escolas linguísticas que o sucederam, do Estruturalismo ao arquipélago teórico da Linguística Cognitiva.

Palavras-chave: Gramática histórico-comparativa. Romanística. Línguas Românicas Ibéricas. Morfologia histórica. Formação de palavras.

\begin{abstract}
This article lists the main postulates and some developments of the historical-comparative method applied to Romance languages, leading to the tracking of their incursions or gaps in the appreciation of lexical morphology. Pari passu to that, the present article outlines the fundamental aspects of a proposal for historical-comparative appreciation applied by Lopes (2018) to prefixation in GalicianPortuguese and Castilian, which can be taken as a preliminary basic model for future panromic applications on other morphological lexicogenesis operations, such as suffixation, composition and parasynthesis (and also prefixation, with the inclusion of more linguistic systems, in addition to the two already examined by the above-mentioned morphologist). The idea of an indeniable relevance and currentness of the method for the historic-centric comparison between languages permeates the entire text, provided with renewed guidelines, through theoretical-epistemological reviews subsidized by the advances presented by the language thought schools that succeeded it, from Structuralism to the theoretical archipelago of Cognitive Linguistics.
\end{abstract}

Keywords: Historical-comparative grammar. Romanistic. Iberian Romance Languages. Historical morphology. Word formation. 


\section{Introdução}

Neste artigo, com base na literatura especializada, buscaremos discorrer sumariamente sobre elementos capitais da gramática histórico-comparativa e o desenvolvimento de seu método, contextualizando-os historiograficamente, apontando os seus postulados mais significativos e as suas contribuições mais expressivas ao estudo científico da língua, não deixando ocultas, no entanto, as suas possíveis limitações.

Não ambicionando qualquer pretensão de esgotar o tema - que é amplo e complexo, pois a escola comparativista não se identifica com um movimento científico unificado (LINHARES, 2015) -, e pautando-nos nos materiais acadêmico-científicos encontrados, intentaremos também distinguir algumas aplicações do método aos estudos lexicais e morfológicos em geral e aos derivacionais em particular, sejam mais antigas, sejam mais contemporâneas, com foco especial nas aplicações às línguas românicas.

Como arremate do artigo, delinearemos o traçado geral de uma proposta de emprego hodierno do método em um estudo morfolexical concernente à Ibero-România, aplicando a um domínio mais amplo, como a afixação ou mesmo a lexicogênese de natureza morfológica em geral, o instrumental histórico-comparativo que Lopes (2018) empregou em seu estudo doutoral à prefixação do castelhano e do galego-português. Dito de outro modo, pretendemos explicitar o delineamento de um modelo de comparação histórica para a formação de palavras, com as suas peculiaridades, justificativas, novidades, ajustes e, inclusive, questionamentos e lacunas. Em suma, buscaremos dar mostras da pertinência e utilidade da aplicação do método histórico-comparativo a análises da geração lexical processada mediante operações morfológicas, o que resultaria tanto em uma melhor compreensão do fenômeno lexicogênico em si, quanto em uma compreensão mais acurada dos mecanismos internos de arcaização, inovação, ramificação e paradigmatização de unidades e operações morfolexicais no âmbito da România, no fluxo histórico subjacente ao desenvolvimento de seu multifacetado espectro linguístico.

\section{Contextualização historiográfica sumária da gramática histórico-comparativa}

A linguística histórico-comparativa, igualmente denominada de gramática históricocomparativa, não obstante a importância dos estágios ou escolas anteriores, significou um salto qualitativo de grande expressão na trajetória da ciência da linguagem, um marco divisor (PAIXÃO 
DE SOUZA, 2006), sendo não poucos os autores que a consideram como a etapa inicial do estudo científico sobre a língua (CYRANKA, 2014; FARACO, 2004; MUÑOZ, 1978; IORDAN, 1973 [1962]) ou, no mínimo, uma das fases mais significativas para a constituição da linguística enquanto ciência (LINHARES, 2015; MORENO CABRERA, 1997).

Apesar de inúmeros manuais de filologia românica ou de história da linguística divisarem Rasmus Rask (1787-1832) ou Franz Bopp (1791-1867) como os inauguradores dessa primeira corrente científica dos estudos sobre a língua, não parece haver unanimidade no acatamento do marco inicial do paradigma em questão exclusivamente a partir do labor desses dois grandes estudiosos. Viaro (2011), por exemplo, parece alçar Sámuel Gyarmathi (1751-1830) à condição de primeiro investigador do ramo, por sua atenção para com o tratamento empírico dos dados e por sua análise austera, que o levaram não apenas à constatação de semelhanças entre as línguas urálicas (privilegiando, por primeira vez no cotejo, as formas gramaticais, em vez das lexicais), mas à própria hipótese da gênese comum dessas línguas, conjunção que, de certo modo, já caracteriza uma perspectiva histórico-comparativa. Sendo assim, Gyarmathi antecederia as inúmeras investigações que se desenvolveriam sobre o indo-europeu. É possível considerar, portanto, em consonância com Viaro (2013), que, juntamente com James Burnett (1714-1799), William Jones (1746-1794), Karl Wilhelm Friedrich von Schlegel (1772-1829) - apontado por Faraco (2005) como o iniciador dos estudos comparativistas entre os alemães -, Jonathan Edwards Jr. (1745-1801) e Johann Christoph Adelung (1732-1802), foi Gyarmathi um notável precursor da gramática comparativa.

A ênfase dos manuais de historiografia linguística nos nomes de Rask e Bopp como expoentes iniciais do método histórico-comparativo (e da primeira fase científica dos estudos sobre a língua) não deve ser fortuita, mas sim, pautada em alguma evidência corroborável. O próprio Viaro (2011) afirma que o século XIX, comparado com o anterior, ofereceu ao estudo histórico-diacrônico um salto qualitativo e isso se deveu, seguramente, às incursões investigativas e publicações do dinamarquês Rask e do alemão Bopp, baluartes na elaboração e maturação do método histórico-comparativo. Esse então parece ser o ponto-chave para a compreensão do destaque que se dá aos dois linguistas mencionados: o foco no método, na elaboração de uma epistemologia própria ao estudo que pretendiam realizar, subsidiados, é claro, pela contribuição dos predecessores, mas lançados como vanguardistas no desenvolvimento controlado e verificável de seu método de análise e de cotejo das línguas.

No esteio de seus predecessores, surge a figura de Friedrich Christian Diez (1794-1876), que, num recorte metodológico muito feliz, restringiu-se à comparação histórica das línguas românicas entre si e entre a sua matriz comum latina. Segundo Viaro (2011, p. 83; 2013, p. 50), “[...] foi Diez quem conseguiu reunir amplos e heterogêneos aspectos linguísticos e filológicos acerca das línguas românicas literárias mais importantes [...], filiando-as ao latim vulgar.”. Foi esse linguista alemão que 
propiciou à filologia românica a sua esquematicidade (NASCENTES, 2009 [1954]), sendo considerado, com justa razão, o seu mentor, não se desprezando, contudo, as robustas contribuições fornecidas à área por August Schlegel (1767-1845) e François-Juste-Marie Raynouard (1761-1831) — a quem Diez considerava o fundador da filologia românica (NASCENTES, 2009 [1954]; RENZI, 1982 [1976]; IORDAN, 1973 [1962]) —, que podem ser apontados como seus precursores (VIARO, 2011). Ainda segundo Viaro (2013), a gramática comparada de Diez (Grammatik der Romanischen Sprachen) e o seu dicionário (Etymologisches Wörterbuch der Romanischen Sprachen) converteram-se em colunas fundamentais para a filologia românica e para a linguística como um todo, contribuindo para a sua cientificidade, o que também é notado por Tagliavini (1973 [1949]).

Todo esse fluxo constitutivo inicial da práxis comparativa na linguística mostra-se numa espécie de genealogia, que remonta, no Ocidente, a Dante, Nebrija e a Nunes de Leão, perpassa pelas figuras pioneiras de Bopp, Rask, Grimm e Schlegel e culmina com Diez e Wilhelm Meyer-Lübke (18611936), no período áureo da filologia românica, sendo a estruturação científica desta última devedora das contribuições dos neogramáticos (VIDOS, 1996 [1956]; RENZI, 1982 [1976]). Com a sua gramática das línguas românicas (dedicada, em três tomos, à fonética, à morfologia e à sintaxe) e o seu dicionário etimológico (Romanisches Etymologisches Wörterbuch - REW), Meyer-Lübke logrou sintetizar e aprimorar todos os resultados anteriormente alcançados pelos comparativistas românicos (sobretudo os realizados pelos neogramáticos), tendo sido o responsável em aplicar o método de reconstrução de Schleicher às línguas neolatinas, com o intuito de reconstruir o latim vulgar, aperfeiçoando os repertórios românicos de Diez (VIARO, 2013; RENZI, 1982 [1976]; BASSETTO, 2005).

Não é supérfluo salientar que o método histórico-comparativo não se tornou obsoleto nem inexequível após a época de seu esplendor (segunda metade do século XIX), como se verá mais adiante, apesar de ter conhecido desde então um abandono paulatino, causado pelo desinteresse geral em relação à perspectiva diacrônica a partir da difusão do estruturalismo, algo que só tomaria outra feição na segunda metade do século XX.

\section{Algumas notas sobre o método e os postulados da gramática histórico-comparativa}

Em linhas gerais, o método histórico-comparativo - considerado por Campbell (1999) e Soares e Carvalho (2014) como a técnica central e mais importante para a linguística histórica e por Rankin (2005) como a mais estável e exitosa metodologia de toda a história da linguística - fundamenta-se em relacionar elementos de uma língua aos análogos de outra(s) da mesma família, para assim chegar à 
sua origem ou procedência (reconstruindo a sua protolíngua), estudando a diversificação que porventura apresentem e reconstruindo a sua trajetória histórica no interior de cada língua (CROWLEY; BOWERN, 2010; MAURER JR., 1967; LEHMANN, 1969 [1962]). Seus propósitos são claramente sintetizados por Makaev (1969, p. 33), no excerto a seguir:

[...] sur la base d'une comparaison conséquente, systématique, des phonèmes et des morphèmes de toutes les langues constituant une famille génétique déterminée, établir l'état génétiquement initial - la langue-mère - et, sur la base des principes de la chronologie relative, procéder à des coupes chronologiques permettant d'établir l'existence d'archaïsmes ou d'innovations dans une aire déterminée ou dans chaque langue concrète.

De acordo com Linhares (2015), a comparação pode compreender três aspectos: o tipológico (modelos gerais de cada um dos níveis linguísticos), o evolucionista (trajetória histórica das formas lexicais ou gramaticais) e o genético (voltado ao estabelecimento da gênese das línguas). Em geral, nesse último, a reconstrução da protolíngua a partir do cotejo entre as suas descendentes inicia-se pela fonologia (reconstrução do sistema sonoro) e, a partir dela, chega-se à reconstrução do léxico e da sua gramática (CAMPBELL, 1999).

Pode-se dizer que as palavras-chave da práxis histórico-comparativa canônica são cognatos, correspondências, leis fonéticas e reconstrução (MEIRA, 2009), nessa ordem, sendo os seus passos constitutivos (i) a reunião de cognatos (eliminando-se os não cognatos, pseudocognatos ou empréstimos); (ii) o arrolamento das correspondências sonoras regulares perceptíveis a partir da observação desses itens; (iii) a proposta de reconstruções necessárias, desde que sistemáticas, comedidas e pautadas em mudanças plausíveis; (iv) a determinação entre correspondências parcialmente sobrepostas; (v) a avaliação da sistematicidade dos sons reconstruídos, respeitando-se a coerência interna à protolíngua e a tipologia; (vi) a reconstrução de vocábulos (MEIRA, 2009).

Rankin (2005) igualmente arrola as principais etapas de aplicação do método históricocomparativo, mas logra ir além dos níveis fonético e lexical, já que também considera aspectos morfológicos e sintáticos. Salienta que costuma haver superposições entre as etapas, que não seguem uma ordenação rígida e que dão margem a que o processo de reconstrução linguística possa iniciar-se em qualquer ponto do caminho histórico constitutivo dos sistemas linguísticos cotejados. Na escala que esquematiza, divisa a reconstrução de natureza fonológica, vocabular, morfológica e sintática. $\mathrm{Na}$ fonológica, haveria a extração de feixes de correspondências fonológicas, a classificação desses conjuntos, a reconstrução preliminar de protofonemas, a sua análise distribucional e, por fim, ajustes nas reconstruções a partir da consideração de informações tipológicas. Na reconstrução vocabular, 
dar-se-ia a reconstituição de domínios léxico-semânticos mais estruturados dentro do sistema, como o do parentesco ou dos numerais ${ }^{1}$, que subsidiariam a captação de conjuntos afins mais lacunares, seguida da possível reconstrução semântica, ainda que houvesse algum déficit de material lexical. $\mathrm{Na}$ reconstrução morfológica - entendida, segundo o sobredito estudioso, como uma extensão da reconstrução léxico-fonológica -, haveria o estabelecimento de morfemas afins de rara ou difícil atestação, propiciado pela paradigmaticidade atuante no próprio sistema. Finalmente, viria a reconstrução da sintaxe (tida por ele como problemática e controversa, tal como a própria comparação entre estruturas desse nível), com a observação de resquícios de construções (se houver), a harmonização/paralelismo entre elas, bem como a possível consideração de cadeias de gramaticalização e de trajetórias de mudança sintática.

Pode-se dizer que o aspecto central do método são as relações regulares de correspondência entre cognatos e, derivado destas, o traçado do parentesco ou relacionamento entre as línguas (com a determinação da protolíngua comum), fincado na relação histórica entre elas, cujas marcas seriam as semelhanças existentes entre cognatos ou estruturas congêneres. Esses postulados evidenciam os pressupostos basilares do método, que, de acordo com Campbell (1999), resumem-se em quatro assunções: (i) a protolíngua é uniforme, destituída de variação dialetal ou diastrática; (ii) a fragmentação das línguas (a partir da protolíngua) é brusca; (iii) após a cisão da protolíngua, não há contatos subsequentes entre as línguas relacionadas; (iv) a mudança sonora é absolutamente regular. A partir da leitura do texto de Rankin (2005), poderíamos agregar um quinto pressuposto do método: a arbitrariedade da relação entre forma fonológica e significado (i.e., a não-iconicidade). Muitas das críticas ao método parecem fincar-se no rechaço a esses princípios.

Um exemplo simples de aplicação do método histórico-comparativo pode ser esboçado a partir de informações extraídas de Vidos (1996 [1956]) e de Monzó Gallo (2013): a partir da comparação entre os cognatos românicos para 'orelha' - orelha (português), oreja (castelhano), orella (galego, catalão), oreya (asturiano), oriya (sardo), oreille (francês), orecchio (italiano), ureche (romeno), orel'e (friulano), aurelha (provençal), ricchi (siciliano) etc. - , podemos chegar à conclusão de que não advêm diretamente da forma clássica auris, mas através do diminutivo deste, auric(u)la, palavra popular do latim vulgar, registrada já na época clássica, presente, por exemplo, em Plauto, Cícero, Plínio e no próprio Appendix Probi.

Outro exemplo da aplicação do método histórico-comparativo, com a reconstituição de formas de uma protolíngua, é-nos apresentado por Calvet (1996): a partir da observação dos paralelismos sonoros entre as formas correspondentes a oito e noite em espanhol, francês, italiano, português, inglês, dinamarquês, neerlandês e alemão, bem como semelhantes convergências entre o latim, o gótico e o

${ }^{1}$ Também sinalizam nessa direção Millar e Trask (2015). 
grego, chega-se à reconstituição das formas indo-europeias ${ }^{\star}$ okt- e * nokt. A aplicação de leis da fonética histórica, bem como a esquematização da genealogia de cognatos com o escopo de alcançar a língua a que remontam, apresentam-se como práticas recorrentes em estudos da gramática comparativa, ao menos em sua aplicação mais tradicional. Daí ser sinalizado por Walkden (2009) que a reconstrução da história linguística (com a reconstituição de aspectos/elementos da protolíngua) e o estabelecimento/captação de relações filogenéticas sejam dois propósitos centrais do método históricocomparativo.

Os exemplos anteriores, meramente ilustrativos ${ }^{2}$, limitam-se ao arrolamento lexical (embora seja possível explorar, através dos cognatos listados, questões de outra ordem, como a previsibilidade e regularidade de suas mudanças fonéticas), mas, de forma semelhante, poderiam ser estabelecidas comparações referentes a outros níveis linguísticos, como o fonético, o morfológico, o semântico, o sintático e até mesmo o discursivo. Comparando-se um sistema (o fonético-fonológico, morfológico, léxico, semântico) a partir de um rol de cognatos de duas ou mais línguas, tendo em conta a língua da qual descendem, verificar-se-iam as suas similitudes e divergências, bem como a regularidade das mudanças processadas. Cabe dizer que o método não necessariamente se restringe à colação entre unidades, já que pode abarcar comparações entre regras, restrições, condições ou similares, dependendo do modelo de gramática e de estudo adotados (RANKIN, 2005).

Um aspecto que deve ser salientado quanto ao método é que o processo de cotejo e reconstrução histórica que a ele subjaz pode ser ascendente ou descendente, a depender dos objetivos almejados na análise. Para o domínio românico, por exemplo, pode-se partir das línguas neolatinas para chegar-se ao latim vulgar (fluxo ascendente) ou, em sentido contrário, partir deste para chegar-se àquelas (fluxo descendente), como exemplifica Vidos (1996 [1956]).

É por meio do método histórico-comparativo que se pode estabelecer a classificação e o parentesco entre as línguas. A sua importância e pertinência se comprovam em outras contribuições que essa técnica propicia à pesquisa sobre relações genéticas distantes e à pré-história linguística, como assinala Campbell (1999). Afirma Lehmann (1962, p. 107) que "Especially for prehistoric languages, a surer method of defining change and determining earlier forms has been developed which is known as the comparative method." São inúmeros os autores que enfatizam a importância desse paradigma de estudo linguístico, sua utilidade, seu rigor e seu potencial explicativo, a exemplo de Joseph (2016).

Como seria de se esperar, o método próprio à linguística histórico-comparativa, além de seus inúmeros méritos e contribuições, tem também as suas limitações, de ordem temporal, sócio-histórica e linguística propriamente dita (HARRISON, 2005). Segundo Martelotta (2012), as principais críticas

\footnotetext{
${ }^{2}$ Para uma exemplificação mais minuciosa da aplicação do método comparativo e da reconstrução linguística, cf. o capítulo 5 do estudo de Campbell (1999) e o capítulo 8 da obra de Millar e Trask (2015).
} 
ao método são as seguintes: (i) apego ao componente histórico das línguas, sem as observar em seu funcionamento como instrumento de comunicação; (ii) observação imanentista, com primazia absoluta da história interna, sem muita preocupação com fatores externos; (iii) abordagem atomística, com a verificação isolada de cada unidade formal sob análise, sem observar o seu funcionamento no interior dos sistemas linguísticos em que atuam. Outro déficit substancial do método parece ser a precária ou inexistente consideração de efeitos do contato - e de fenômenos e processos a ele afeitos -, algo de indiscutível importância na conformação de famílias linguísticas, claramente atuante, por exemplo, no âmbito românico.

\section{Informe conciso sobre algumas aplicações contemporâneas do método histórico-comparativo}

É falso e redutor o pensamento de que a linguística histórico-comparativa foi um período pré ou pseudocientífico para a ciência da linguagem e que tenha estagnado no século XIX, sendo incompatível com a linguística moderna. Starostin (2000), afastando-se expressamente de um diagnóstico negativo, chega a afirmar que as últimas décadas do século XX (e, por extensão, também as primeiras do século XXI) têm testemunhado grandes avanços nas técnicas da área, com o advento de especialidades ou subcorrentes dentro do comparativismo, como as que se atrelam à lexicoestatística e à glotocronologia. Chega a afirmar (2013) que a última década testemunhou uma explosão de estudos sobre a aplicabilidade de modelos baseados em redes $^{3}$ para a classificação linguística. Moreno Cabrera (1997, p. 78) aponta na mesma direção, enfatizando que a linguística histórico-comparativa é uma disciplina com um imenso potencial teórico e heurístico, totalmente atual, "[...] un dominio científico vivo y palpitante, quizás [...] más vivo y palpitante que nunca.”

Segundo Viaro (2013), novas aplicações (muitas vezes revisadas) do método históricocomparativo desenvolveram-se durante todo o século XX, como as efetuadas por Greenberg (19152001), primeiro com a comparação entre línguas da África, depois com as da Nova Guiné e, por fim, com o cotejo de línguas da América (desde 1949 até a década de 80), chegando a propor, em 2000, o

\footnotetext{
${ }^{3}$ Segundo Heggarty, Maguire e McMahon (2010), modelos analítico-representacionais de redes são uma alternativa viável ao modelo arbóreo tradicional (árvore ramificada/genealógica) e ao modelo de ondas de difusão. Tomados da biologia (nomeadamente, da genética), os modelos de redes são aplicáveis a diferentes tipos de dados linguísticos e a análises léxico-estatísticas, sendo dois dos seus algoritmos/programas mais destacados o Network (BANDELT et al., 1995; BANDELT; FORSTER; RÖHL, 1999) e o NeighborNet (BRYANT; MOULTON, 2004; HUSON; BRYANT, 2006). Uma das principais vantagens do modelo de redes, sobretudo o NeighborNet, é a sua capacidade de exibir distâncias em pares entre os táxons na forma de agrupamentos cruzados e a sua possibilidade de capturar visualmente as teias e emaranhados típicos da maioria das famílias linguísticas, evidenciando as suas conexões (cf. FRANÇOIS, 2014).
} 
euroasiático. Concomitantemente, pesquisadores russos como Illič-Svityč (1934-1966) e Dolgopolsky (1930-2012), aplicando rigorosamente o método histórico-comparativo, propuseram a reunião do grupo indo-europeu, o afroasiático, o kartveliano, o urálico, o altaico e o dravídico, retomando a antiga hipótese de Pedersen (1903) sobre o nostrático.

Outras propostas de relação e filiação genética foram lançadas e seguem sendo lançadas (basta pensarmos no exemplo das línguas austronésias), sobretudo a partir do surgimento da paleolinguística. Um exemplo é o estudo de Ratcliffe (2003), voltado à comparação do léxico na família afro-asiática. Outros exemplos, mais voltados às línguas românicas, são: (i) o estudo de Sánchez Miret (2008) sobre a metafonia, a influência de sons palatais sobre as vogais e a sua possível conexão com a ditongação em algumas dessas línguas, como o castelhano; (ii) o já mencionado estudo de Monzó Gallo (2013), em que compara os cognatos românicos para 'nariz', 'olho' e 'orelha'; (iii) o trabalho de Tejero Benéitez (2012) sobre as perífrases verbais no latim e nas línguas neolatinas, sob um viés também comparativo.

Os estudos de Walkden (2009) e Eythórsson e Barðdal (2016) demonstram ainda a vitalidade/validade da aplicação do método histórico-comparativo à reconstrução sintática e à detecção de correspondências interlinguísticas entre estruturas pertencentes a esse nível da língua. Esses dois últimos autores demonstram, inclusive, as vantagens do aproveitamento do marco teórico da Gramática de Construções pelo labor comparativista de reconstrução de estruturas/relações sintáticas, o que certamente contradiz a falsa impressão de um imobilismo ou estagnação da gramática comparativa frente aos desenvolvimentos teóricos da linguística contemporânea.

Com o advento da informática, a aplicação do método não ficou alheia às suas inovações, havendo novas investigações subsidiadas por corpora digitais ou por ferramentas específicas de depreensão e análise de categorias linguísticas. Tomemos como exemplo a tese de Rama (2009), com a sua proposta de automatização da identificação de cognatos e a aplicação de técnicas de bioinformática para a construção de árvores filogenéticas para as línguas.

Um campo em que a aplicação da técnica linguístico-comparativa tem apresentado uma produtividade expressiva é a lexicoestatística, desde a sua gênese, pelos idos de 1950, com as investigações de Swadesh. A escola de linguística comparada de Moscou e o Santa Fe Institute (Novo México, EUA) têm sido prolíficos nesse âmbito, adotando-a como procedimento basal para as suas abordagens comparativistas.

De acordo com Starostin (2013; 2010), o método lexicoestatístico (aplicado a muitas famílias linguísticas, sobretudo por ser flexível e de fácil manejo, mas que já sofreu várias críticas, sendo fundo para diversas controvérsias) consiste na avaliação do grau de parentesco genético entre diferentes línguas (e a subsequente construção de árvores genealógicas), a partir de percentuais de itens historicamente relacionados em seu léxico comum. Tradicionalmente, a comparação se pauta em uma 
lista de duzentas (na versão estendida) ou cem palavras (na versão comprimida) pré-estabelecidas, extraídas do léxico básico, ainda que propostas mais recentes, como a do próprio Starostin (2010), preconizem a condensação dessa lista em cinquenta itens léxicos. Uma síntese explicativa do método tradicional de Swadesh encontra-se exposta no artigo de Starostin (2013), em que aborda a lexicoestatística e a glotocronologia. Para esse último linguista, a lexicoestatística não se opõe ao método comparativo canônico; pelo contrário, pode ser vista como uma técnica complementar, que deve acompanhá-la, para lhe propiciar uma base quantitativa adequada, o que, até então, não tem sido oferecido satisfatoriamente por outra técnica.

Abordagens mais léxico-estatísticas e/ou computacionais do método histórico-comparativo têm trazido interessantes contribuições a esse campo investigativo, como as publicações de Ringe, Warnow e Taylor (2002), McMahon e McMahon (2003), Bryant, Filimon e Gray (2005), dentre várias outras. A proposição teórica e a aplicação analítica de modelos inovadores de relação/ hierarquização/organização interlinguística, para além da representação arbórea (como a de ondas, redes ou teias) e/ou em contraste a postulados cladísticos, por exemplo, são mostras das revisões e reflexões constantes a que o método tem sido submetido na contemporaneidade, como as esboçadas por François (2014), Nichols e Warnow (2008), Kessler (2008), Heggarty, Maguire e McMahon (2010), bem como os estudos reunidos no fascículo organizado por Kalyan, François e Hammarström (2019).

Para finalizar a demonstração da vitalidade da gramática histórico-comparativa na contemporaneidade, podemos evocar como outras mostras dessa realidade:

(i) o grande número de estudos dessa natureza que focaram as línguas nativas brasileiras, sobretudo os de Aryon Rodrigues - expoente da linguística histórica voltada às línguas autóctones do país e discípulo de Mansur Guérios, o pioneiro da linguística histórico-comparativa no Brasil —, mas também de outros investigadores, como Mello (2000), Ramirez (2001) e Camargos (2013);

(ii) as centenas de artigos reunidos em plataformas bibliográficas (e.g., o The Tower of Babel Electronic Library) ou em revistas digitais que versam sobre o tema (e.g., o Journal of Language Relationship, na Rússia; a Zeitschrift für romanische Philologie e a Romanische Forschungen, na Alemanha; a Revue des langues romanes, a Romania e a Revue de Linguistique Romane, na França; a Vox Romanica, na Suíça; La Corónica: A Journal of Medieval Hispanic Languages, Literatures, and Cultures, nos Estados Unidos; a Revista de Filología Románica, a Estudios Románicos e a Estudis Romànics, na Espanha; a Caligrama: Revista de Estudos Românicos, no Brasil; 
(iii) alguns congressos específicos de romanística, como o Congrès International de linguistique et de Philologie Romanes, o Linguistic Symposium on Romance Languages e o Romanistentag des Deutschen Romanistenverbandes;

(iv) os grandes (embora poucos) projetos coletivos voltados à comparação interlinguística com base no método mencionado, como, por exemplo, (a) o The Tower of Babel, que visa a manter conexões de longo alcance entre famílias linguísticas estabelecidas do mundo, disponibilizando um banco de dados com as listas de palavras básicas (i.e., as Swadesh word-lists) das línguas de todo o orbe, o The Global Lexicostatistical Database; ou (b) o Romanische Sprachgeschichte: Ein internationales Handbuch zur Geschichte der Romanischen Sprachen, anunciado desde 1990, que visou ao estabelecimento de manuais internacionais de história das línguas românicas e da formação global de seus domínios, tomando como lastro a metodologia da linguística histórica associada a disciplinas científicas afins (HOLTUS; SÁNCHEZ MIRET, 2008);

(v) o quadro atual, com mais de setecentos membros, da Société de Linguistique Romane, fundada em Paris, em 1924.

Apesar do quadro animador para os estudos histórico-comparativos em geral, com o destaque de algumas escolas e países onde vicejam na contemporaneidade, o mesmo não parece ocorrer exatamente para os estudos de filologia românica comparada no âmbito brasileiro ${ }^{4}$ (embora no passado fosse possante, com produções que se projetavam, inclusive, internacionalmente). São poucos os estudos dessa área no país, sendo ainda mais raros os grupos de pesquisa a ela voltados ou os projetos coletivos oficiais destinados a essa proposta. Situação similar parece ocorrer em Portugal, pelo que se lê em Kabatek (2007). Mesmo quanto à assunção de que em âmbito mundial (ou ao menos europeu) a filologia românica comparada segue vigorosa, podem ser apresentadas ressalvas, pois, ao que parece, tem passado a ocupar um segundo plano, com a predominância e o alçamento de investigações históricas monolíngues (especializando-se na história de uma língua) em que a perspectiva panromânica praticamente está desvanecida (HOLTUS; SÁNCHEZ MIRET, 2008; GIRÓN, 2005; DWORKIN, 2003) 5 .

\footnotetext{
${ }^{4} \mathrm{Ou}$, se nos fiamos nas impressões de Ridruejo (2005), também para o contexto africano, asiático e ibero-americano, áreas em que o cultivo da disciplina é quase excepcional.

${ }^{5}$ A avaliação do status da filologia românica comparativa em escala global na contemporaneidade não é simples. Tampouco goza de consenso entre os linguistas, embora se observe, na maior parte dos casos, pareceres negativos. Vejamos uma amostra representativa da divergência de opiniões quanto à vitalidade da disciplina, extraída de um artigo de Company Company (2005, p. 144): "Por un lado, [hay] los colegas que muestran un fuerte o moderado pesimismo respecto de la vitalidad de la lingüística histórica románica como área disciplinaria de estudio (Craddock, Dworkin, Loporcaro, Lüdtke, Pellen, Rini), y, por otro, aquellos colegas, esencialmente optimistas, que consideran que la lingüística romance goza de cabal (Kabatek, Koch, Penny) e incluso de excelente salud (Echenique, Wanner, Wright).
} 


\section{O método histórico-comparativo aplicado aos estudos de morfologia lexical}

O intuito desta seção é apresentar sinopticamente algumas aplicações do método históricocomparativo à lexicogênese, sobretudo românica. Para tanto, procedemos a uma varredura nãoexaustiva, representativa, pelos fundos bibliográficos disponíveis em formato digital na rede. Ao lado da exposição dos estudos encontrados, lançamo-nos a uma avaliação geral sobre o locus da morfologia lexical nos estudos comparativistas históricos.

Uma das principais críticas ao método histórico-comparativo refere-se à primazia da fonética em suas reflexões (MAURER JR., 1967; VIDOS, 1996 [1956]; TRASK, 1996), sendo aplicações muito mais voltadas a esse âmbito do que a qualquer outro da língua (RANKIN, 2005). A causa dessa predileção é associada por Vidos (1996 [1956]) à grande regularidade desse nível linguístico e, segundo Kilbury e Bontcheva (2004), foi através dela (mais precisamente, das correspondências sonoras) que a linguística comparativa alcançou uma base metodológica firme para as reconstruções propostas.

Outros autores, não deixando de indicar a preferência concedida à fonética pelo método, estendem-na um pouco mais, com a inclusão do nível lexical e, sobretudo, do morfológico (BARĐDAL, 2013; GARR, 2005; RANKIN, 2005). Cabe buscar refletir sobre dois aspectos a partir desse cenário: a situação do componente sintático e, principalmente, o tratamento comparativo da lexicogênese (i.e., se a comparação morfológica também contemplava a formação de palavras).

Rankin (2005) parece justificar a carência de aplicações da técnica histórico-comparativa ao componente sintático ou impasses nessa prática pela dificuldade em se determinar as unidades de colação para esse nível (no fonético, seriam os fonemas; no morfológico, os morfemas; no lexical, os lexemas; mas qual seria para a sintaxe? Como definir sentenças ou sintagmas cognatos? Algo nada simples de se resolver...) e, mais ainda, à dificuldade de se medir com algum grau satisfatório de precisão (tal como é feito para os outros níveis linguísticos) as correspondências semânticas ou formais entre as estruturas sintáticas acareadas. Iordan (1973 [1962]) e Bassetto (2005) fazem eco a esse ponto de vista, afirmando que para a sintaxe é mais difícil comprovar a regularidade das correspondências, que é o fundamento da técnica comparativo-histórica, e daí não se ter revelado profícua nesse ponto, apesar de brotarem algumas tentativas de estudo, como as pautadas na visão pancrônica de Walther von Waltburg (BASSETTO, 2005).

Otros colegas (Smith, Wireback) se decantan por una opinión intermedia: la lingüística histórica romance es una disciplina moribunda, pero el estudio diacrónico de las lenguas romances particulares mantiene plena vitalidad.” 
Que os estudos sintáticos de natureza histórico-comparativa tenham sido mais escassos do que os voltados a outros níveis linguísticos é fato comprovável. Talvez o que não se possa dizer categoricamente é que as causas comumente apontadas para tal sejam verossímeis. Para Barðdal (2013), parece que não, pois assinala que as objeções evocadas para a marginalização da sintaxe na práxis comparativa - a ausência de cognatos sintáticos, a falta de emparelhamentos arbitrários entre forma e função sintáticas e a falta de regularidade na mudança desse tipo - são frágeis quando observadas aprofundadamente. Atualmente, já se verifica a existência de diversos estudos comparativos no campo sintático. Company Company (2005), destoando do que se costuma afirmar, desenha um panorama positivo para a sintaxe românica histórica (e, em certa medida, também para a comparada) nos últimos anos, considerando que "[...] ha pasado de ser el patito feo de la lingüística histórica, romance y general, con una escasez notoria de estudios y estudiosos hace cincuenta años [...] a ser el cisne de las subdisciplinas diacrónicas hoy en día.” (COMPANY COMPANY, 2005, p. 145).

No que concerne à situação da morfologia lexical no quadro comparativista, é de se pensar que também não seja das mais favoráveis, quiçá ainda mais grave (no passado e no presente) que a da sintaxe. Como já dito, houve uma incidência do método no componente morfológico, mas, pelo que parece, voltado quase que exclusivamente à morfologia flexional (RIDRUEJO, 1989), e não à morfologia lexical. Seria temerário afirmar que não houve estudos dessa seara referentes à lexicogênese, mas, ao que parece, não foram muitos.

Lindner (2015) registra que no século XIX ainda era muito incipiente a análise comparativa (e mesmo geral) da formação de palavras. A morfologia podia ainda ser tratada como parte da etimologia, embora já emergisse em algumas obras uma separação, com um tratamento específico da formação genolexical de cunho morfológico ${ }^{6}$. Ainda conforme essa autora, foi Grimm (1826) que inaugurou a aplicação do método histórico-comparativo à formação de palavras, incidindo sobre o germânico, cotejando-o com outras línguas, havendo também aproximações ao tema por parte de Bopp (1833) e Pott (1836).

Iordan (1973 [1962]) indica que na Grammatik der Romanischen Sprachen (1838), de Diez, são feitas comparações de morfologia derivacional das línguas românicas, o que é reforçado por Lindner (2015), que considera tais contribuições como um importante tratado para a formação de palavras no círculo comparativista histórico. Cyranka (2014) afirma que Pott, levando adiante os trabalhos de Bopp e Grimm, explorou a derivação vocabular em suas aplicações do método histórico-comparativo. No entanto, para essa primeira etapa da corrente linguística em discussão, segundo Lindner (2015), o nome de destaque seria o de Brugmann (em seu Grundriß der vergleichenden Grammatik der indogermanischen Sprachen, de 1880 e 1906), com um volume monumental para a descrição e

\footnotetext{
${ }^{6}$ Sobre formações/mecanismos/paradigmas genolexicais, cf. Rio-Torto (1998).
} 
comparação da formação de palavras em línguas indo-europeias, discorrendo sobre os tipos de processos de formação, as suas motivações e sobre a composição morfológica. Para os séculos XX e XXI, Lindner (2015) elenca uma variedade de estudos sobre o tema, mas a maioria deles numa perspectiva monolíngue (para o latim, o antigo índico, o grego etc.), sendo poucos os efetivamente panlinguísticos, como os de Delbrück (1900), os de Brugmann $(1904,1906)$ e os mais recentes de todos, presentes nos dois tomos do quarto volume da Indogermanische Grammatik, organizados por Linder (2015) e Sadovski (2016), respectivamente.

Especificamente para o âmbito da romanística, Holtus e Sánchez Miret (2008) afirmam que a perspectiva comparativa na formação de palavras foi abordada em uma das edições do Romanistentag des Deutschen Romanistenverbandes, mencionando Gauger (1988). Não obstante, o quadro para esse campo não parece ser animador, o que é confirmado por Sánchez Miret (2001) e por inúmeros outros teóricos da área - Stolova (2005), por exemplo —, quando asseveram que tais estudos não costumam ser nem históricos nem comparativos, "desrespeitando-se", de certa forma, a própria natureza caracterizante da disciplina, sendo comumente dominados pelas teorias gerativistas. Exceções nesse sentido são os trabalhos de Meyer-Lübke (1890-1906), Cooper (1895), Malkiel (1945), Bader (1962), Lloyd (1964), Bagola (1988) e Lüdtke (1993), dentre alguns outros mais (SÁNCHEZ MIRET, 2001).

Dentro dessas honrosas exceções, mencionamos ainda três estudos de aplicação históricocomparativa à formação de palavras: (i) o capítulo A formação de palavras na România Ocidental, parte do livro A unidade da România Ocidental, de Maurer Jr. (1951), que oferece uma sistemática descrição panromânica de usos e sentidos das principais unidades prefixais e sufixais, bem como dos padrões compositivos mais recorrentes; (ii) o artigo Gemeinromanische Tendenzen IV: Wortbildungslehre, de Lüdtke (1996) - incrustado no primeiro tomo do segundo volume da monumental obra Lexikon der Romanistischen Linguistik, organizado por Holtus, Metzeltin e Schmitt (1996) -, que traz algumas considerações sobre o comportamento de formativos afixais no latim e no âmbito românico; (iii) o livro intitulado La formación de palabras en las lenguas románicas: su semántica en diacronía y sincronía, do mesmo Lüdtke (2011), que, tece diversos comentários à formação de palavras em sua evolução do o latim ao romance.

Vários dos estudos mencionados acima servem para corroborar a legitimidade da percepção de que, embora raros, há ainda na contemporaneidade projetos, estudos e publicações concernentes ao âmbito teórico-metodológico em tela, não tendo estagnado em fins do século XIX, ou seja, não tendo ficado encapsulados em práticas investigativas anteriores às novidades epistemológicas que brotaram no século seguinte, como o estruturalismo, o gerativismo, o funcionalismo e o cognitivismo.

No espaço brasileiro, os estudos de lexicogênese românica comparada nem foram nem são numerosos, devido ao tratamento tangencial da morfologia no panorama investigativo em geral, à marginalização da perspectiva de análise diacrônica para a língua (só há poucas décadas 
experimentando alguma reabilitação, com fulgor e vitalidade, mas de forma marcadamente localizada, concentrando-se em meia dúzia de universidades) e, dentro desse último fenômeno, o engessamento ou fenecimento das cadeiras, grupos de pesquisa, revistas especializadas e demais publicações específicas concernentes à filologia românica, especialidade cujo ensino só tardiamente foi inserido no país (NASCENTES, 1961), quando comparado à realidade de outros países, notadamente os europeus.

Os raríssimos estudos sobre formação de palavras encontrados, versam, em geral, sobre a sufixação e são de autoria de investigadores da Universidade de São Paulo, fato que se explica, possivelmente, pela sua cátedra de estudos românicos, pela tradição de linguística-histórica ali presente e, especialmente, pela constituição do Grupo de Morfologia Histórica do Português (GMHP), fundado pelo Prof. Mário Viaro, no ano de 2005. São principalmente os estudos desenvolvidos por Freitas (2014), com uma colação dos derivados em -mento nas línguas românicas; Areán-García (2007, 2011), ao comparar historicamente os sufixos -ista e -ístico(a) no português e no galego; e Condé (2013), com o cotejo de derivados em -aría/-ería também nesses sistemas linguísticos.

Uma notável exceção quanto a essa concentração territorial-institucional dos estudos históricocomparativos aplicados à formação de palavras é a recente tese de Simões Neto (2020), desenvolvida na Universidade Federal da Bahia. Trata-se de um estudo comparativo, cognitivo e construcional do esquema $X$-ari- do latim às línguas românicas (considerando o romeno, o italiano, o francês, o catalão, o espanhol, o galego e o português), pautado em pressupostos da Semântica Cognitiva, da Gramática Cognitiva, da Gramática de Construções, da Morfologia Construcional e do modelo dos Mapas Semânticos de Haspelmath (2003).

Quanto à prefixação, sob um prisma histórico-comparado, um dos poucos redutos acadêmicos no país onde tem surgido alguma investigação sistemática que a contemple, é também a Universidade Federal da Bahia, com as investigações levadas a cabo ou em desenvolvimento pelo docente autor deste artigo e seus discípulos.

Do discutido nesta seção, podemos concluir que a formação de palavras foi contemplada (e segue sendo) pela técnica histórico-comparativa, mas em grau inferior a outros temas, como a fonologia e a morfologia flexional ${ }^{7}$. Além disso, para os estudos românicos, o quadro parece ser mais desanimador, ao que se soma a dificuldade (pelo menos para um pesquisador brasileiro) em rastrear e, sobretudo, ter acesso eficiente, às publicações de morfologia derivacional histórico-comparativa, por várias razões,

\footnotetext{
${ }^{7}$ Um exemplo ilustrativo é o que ocorre no âmbito da linguística histórica hispânica, pois espelha o que ocorre em outras zonas de tradição investigativa na romanística (imaginemos, então, como não o será em áreas onde não existe tal tradição...): segundo Álvarez de Miranda (2005), dentre todas as disciplinas da linguística histórica (e, dentro dela, a histórico-comparada, podemos dizer) as mais deficitárias são aquelas concernentes ao componente lexical, como a história do léxico, a etimologia e a lexicografia histórica. Não seria exagero incluir nesse rol a lexicogênese de cariz morfológico.
} 
sendo algumas delas os preços exorbitantes das obras disponíveis à venda na internet e o fato de muitas estarem redigidas em alemão, língua de domínio não muito corrente ${ }^{8}$. Cabe ainda dizer que a maioria das informações coletadas sobre esses estudos parece atrelá-los à sufixação, raramente sendo possível se deparar com publicações efetivamente relativas à derivação prefixal ou à composição, seja no passado, seja no presente.

\section{Proposta de aplicação do método histórico-comparativo à morfologia lexical e à prefixação}

Da leitura das seções anteriores, já é possível chegar a uma inferência de que a prefixação não gozou nem goza de grande atenção na investigação histórico-comparativa, nem mesmo na área da romanística, de tal sorte que não exageramos ao dizer que, com certa frequência, quando os estudos foram/são morfolexicais, não foram/são histórico-comparativos e quando foram/são históricocomparativos, não o foram/são morfolexicais.

Um dos fins deste artigo, como apontado em sua introdução, consiste na tentativa de desenho de um plano geral para cotejamento histórico da formação de palavras prefixadas, o que talvez possa fomentar o desenvolvimento de estudos histórico-comparativos voltados a esse e a outros procedimentos de geração morfolexical, como a composição, a parassíntese e a sufixação. Como exemplificação, principiemos, pois, pelo que consideraríamos como uma proposta ideal de investigação comparativa e histórica para a prefixação na Ibero-România que satisfizesse as condições e principais pautas da linguística histórica, da romanística e do método histórico-comparativo. Seguramente, um projeto dotado de todos os seguintes traços característicos, simultaneamente:

(i) abarcador de todas as línguas românicas peninsulares de cultivo histórico que gozassem de documentação remanescente satisfatória (i.e., suficiente), como o galego, o português, o castelhano, o catalão, o asturo-leonês, o mirandês e o aragonês';

(ii) abrangedor de toda a linha histórica de constituição desses sistemas linguísticos, iniciando-se com um prospecto sobre a prefixação no latim clássico, vulgar e

\footnotetext{
${ }^{8}$ Quanto a essa questão, cf. o que sinaliza Dworkin (2005).

${ }^{9}$ Haveria de se verificar, é claro, se todas essas línguas possuem o espectro textual cogentemente requerido para um estudo histórico dessa envergadura. Ainda que o possuam como remanescente, pode ser que não o tenham filologicamente editado, o que a princípio impediria a sua inclusão no lastro documental para estudo.
} 
medieval, seguindo-se a prefixação nos romances, chegando-se à produção primitiva nas línguas neolatinas peninsulares (séculos XI a XIII) e daí inflectindo continuamente até o presente;

(iii) fincado em um lastro teórico heterogêneo (MATTOS E SILVA, 2008) sobre esse processo lexicogenético, pautado em contribuições de teorias estruturalistas, gerativistas e (sócio)cognitivistas pertinentes à morfologia derivacional;

(iv) subsidiado por um lastro empírico textual corroborante de grande alcance (quantitativa e qualitativamente), sendo tipológica, temática e discursivamente diversificado;

(v) pautado na depreensão léxico-morfológica e na análise dos formantes e derivados, através de ferramentas de processamento automático aliadas à anotação manual, devido às carências ainda existentes para um estudo informatizado ligado à formação de palavras (LOPES, 2018);

(vi) propiciador de uma análise morfológica concomitantemente horizontal e vertical, a primeira trazendo uma visão panorâmica, sobre a constelação prefixal em cada uma das línguas - nos moldes dos estudos de Soledade (2004), Santos (2009) e López Viñas (2012) —; e a segunda, por sua vez, fincada numa análise profunda de cada um dos formativos e de suas redes morfolexicais - nos moldes dos estudos de Díaz García (2006), Simões Neto (2020, 2016) e Santos (2016) -, também para cada uma das línguas, em ambos os casos cobrindo todo o seu percurso constitutivo, como preconiza o item (ii) supra;

(vii) englobador de todos ou dos principais aspectos relacionados ao fenômeno derivacional analisado, sejam etimológicos, morfolexicais, morfofonológicos, morfossintáticos, morfopragmáticos, abarcando, inclusive, as questões de produtividade e vitalidade, lexicocronologia (SÁNCHEZ MIRET, 2001), gramaticalização, lexicalização, desgramaticalização, substituição de prefixos, transcategorização, superposição de partículas etc.;

(viii) empreendedor de um processo de colação de mão dupla, de caráter retrospectivo (dos cognatos ibero-românicos à forma original latina) e prospectivo (no sentido inverso), que possibilite a observação e a análise dos fluxos de convergência e divergência entre os formantes (tanto no aspecto formal quanto no semântico ou funcional), com as possíveis flutuações variacionais e fluxos de mudança em todos os cruzamentos panromânicos possíveis. 
Como podemos inferir, a feitura apropriada de um estudo desse alcance, que acoplasse em si todos esses aspectos, ainda que muito desejada, seria impossível para um curto prazo, pois seria um projeto multifacetado e com muitos obstáculos a superar, exigindo, indubitavelmente, a constituição de um grupo de pesquisa numeroso, que a ele se dedicaria por muitos anos (talvez por mais de uma década), distribuídos em várias etapas, cada uma com um conjunto de metas a serem alcançadas.

Devido ao exposto, ao planejar em 2013 o seu estudo de doutorado, iniciado em 2014 e defendido em 2018, Lopes (2018) ponderou que um projeto histórico-comparativo sobre a prefixação em línguas ibero-românicas para o período de um doutoramento não poderia ousar identificar-se com o projeto geral acima delineado, malgrado muito o quisesse, pois não lograria cumprir todos os seus requisitos e propósitos. Como considera Kabatek (2007, p. 188), "La realización de un proyecto científico siempre lleva, necesariamente, a limitaciones, y por mucho que queramos rehuir a ello, habrá que contentarse con una selección de elementos.”. E foi justamente isso ao que procedeu: um recorte expressivo, que viabilizasse o desenvolvimento de um trabalho ao mesmo tempo factível e pertinente.

A proposta de comparação histórica da tese de Lopes (2018) poderia ser tomada como uma parcela do extenso projeto supramencionado, pois se pauta em vários recortes, a fim de ser exequível. Vinculou-se a apenas dois sistemas linguísticos ibéricos, o castelhano e o galego-português e, em seu fluxo temporal, cingiu-se especificamente ao período alusivo aos séculos XIII a XVI. Com base em um conjunto robusto de dados, incidiu horizontal e verticalmente sobre as formações prefixais, analisando em cada língua as características semântico-funcionais e formais dessas unidades derivativas, o seu percurso etimológico e os conjuntos paradigmáticos que moldavam. Pretendeu satisfazer, portanto, o máximo possível, para cada uma das duas línguas analisadas, os itens (iii), (iv), (v) e (vi) arrolados acima e, na medida do possível, o item (vii).

No que concerne ao item (viii), relativo à técnica de comparação propriamente dita, Lopes (2018) buscou fazê-la, o quanto foi viável, em seu fluxo ascendente e descendente, indo da matriz genolexical latina ao castelhano e galego-português medievais e destes, por sua vez, à sua fonte lexicogênica, em fluxo contínuo, buscando explicitar os nexos de semelhança e as particularidades desses dois idiomas românicos, nas suas duas sincronias arcaicas. Assim sendo, pode-se dizer que foram cumpridos os requisitos principais para um estudo de cariz histórico-comparativo, já que, de acordo com Makaev (1969, p. 34), 
La grammaire historico-contrastive de langues parentes, au sens vrai du mot, est la grammaire des convergences et des divergences que l'on peut observer entre les différentes langues ou les différentes aires linguistiques d'une famille linguistique donnée.

Pelo afirmado acima, vemos que a análise comparativa desenvolvida na tese de Lopes (2018) foi retrospectiva e prospectiva, focando, de um lado, o percurso em direção ao elemento latino (étimo) e, do outro, o decurso em direção ao modelo final subjacente às formas modernas das línguas comparadas (voz hodierna em uso). Em outras palavras: dada uma forma latina, chegou-se às respectivas formas românicas resultantes; e, sob outro prisma, dadas duas ou mais formas românicas, atingiu-se, retrospectivamente, a forma latina inicial correspondente (NASCENTES, 2009 [1954]). Makaev (1969) preconiza que é possível e até mesmo recomendável proceder a um confronto e a uma junção ou síntese dessas duas rotas de análise, como o fez Pottier (1962) na análise das preposições em latim e nas línguas que dele derivaram. Mediante uma observação acurada, seria possível lograr uma percepção das similitudes e diferenças entre os fatos em confronto, viabilizada pelo trânsito contínuo entre as duas vias comparativas aludidas.

Pensamos ser necessário agregar aqui um adendo explicativo a essa ideia da conjunção das duas vias de análise comparativa, visto que não consideramos que as línguas românicas sejam meras “[...] continuadoras del latín hablado en la 'Romania' [...]” ou simplesmente "[...] el resultado actual de las evoluciones y transformaciones ininterrumpidas del latín de los antiguos romanos hasta su fragmentación y la cristalización de las nuevas modalidades lingüísticas, distintas del idioma originario.” (MUNTEANU COLÁN, 2005, p. 19-20).

Pelo contrário, ao repassarmos o fluxo histórico constitutivo dos sistemas linguísticos enfocados, podemos perceber que a composição do quadro românico, com as equivalências, similitudes, divergências e contrastes simultaneamente incidentes sobre os idiomas que o integram, explica-se não somente pela filiação direta a uma língua originante, mas também pelo processamento de um conjunto multivalente de variações, mudanças, transferências, permutas, conexões, interinfluências, choques e concorrências por parte dos sistemas gerados a partir do latim vulgar, num fluxo dinâmico e multiaxial, condicionado (ou pelo menos influenciado) pelo contato (cf., entre outros, KLEE; LYNCH, 2009) e pelo uso, vetores essenciais na estruturação e no funcionamento de qualquer sistema linguístico e necessariamente delineados a partir da ação de causas sociais, políticas, históricas, culturais, estilísticas e discursivas, incrustadas em sociedades e territórios cambiantes e de modo algum estáticos. Ora, essas características desses conglomerados sócio-territoriais eram também de algum modo as dos sistemas linguísticos neles emergentes (MAÍLLO SALGADO, 1998), espraiados num complexo dialetal multifacético, dotado de patente variabilidade: um continuum inicialmente monolíngue (mas de modo algum homogêneo ou uniforme) e posteriormente cindido (WRIGHT, 1998; RAMOS REMEDIOS, 2003), embora mantendo inúmeras conexões e encaixamentos. 
Há que se esclarecer também que não foi objetivo de Lopes (2018) a utilização do cotejo interlinguístico para lançar-se à reconstrução de estágios reais ou possíveis etapas pré-históricas de idiomas (neste caso, o latim), um dos objetivos da prática histórico-comparativa (BARĐDAL, 2013), mas sim, utilizar-se dela como um apoio à investigação do rastreamento de movimentos de variação e mudança no interior das línguas aparentadas. A colação, através da percepção de contrastes e convergências, permitiria uma observação mais clara do comportamento intralinguístico de cada um dos sistemas enfocados e, aliada a isso, uma avaliação do grau de proximidade que estabelecem entre si, devido à manutenção ou não de traços semelhantes e aos respectivos fluxos de mutação e conservação.

Starostin (2000), discorrendo sobre os moldes de comparação entre línguas, destaca a importância de se encontrar as características pertinentes que possam ser adotadas para estabelecer um paralelo entre elas, observando-se a proximidade ou distância que revelam. Recomenda certa cautela no manejo de similitudes sonoras, morfológicas ou sintáticas como pautas de critérios para a comparação, pois podem não propiciar a obtenção de medições equilibradas entre uma língua e outra, já que são sistemas que em uma língua podem ser rapidamente mutáveis e em outra extremamente conservadoras.

As observações de Starostin (2000), ainda que provavelmente destinadas a comparações mais gerais sobre as línguas, trazem à baila inquietações epistemológico-metodológicas, pois é possível se perguntar até que ponto as comparações morfolexicais permitem propor diferenciações ou acercamentos entre uma realidade linguística e a outra? Quais os limites do cotejo para o delineamento de uma caracterização diacrônica dos sistemas comparados, em termos de convergência e distanciamento, sobretudo quando se adota como base mais uma perspectiva qualitativa que quantitativa? A partir de uma investigação dessa natureza seria possível lançar uma hipótese plausível sobre a proximidade ou distanciamento entre dois ou mais sistemas linguísticos quanto à lexicogênese (prefixal, por exemplo)? Quais seriam as pautas de colação pertinentes? Inquietações que perpassam o labor investigativo e para as quais não temos mais que expedientes provisórios, hipotéticos, aproximativos, que nos pareceram os mais aceitáveis. Daí que Lopes (2018) tenha adotado um artifício autorreferente na pesquisa, pois o seu próprio desenrolar é que lhe mostraria quais procedimentos comparativos seriam mais viáveis e interessantes para a análise e confrontação das línguas abordadas. As dúvidas, ao contrário de embaçarem a cientificidade de uma pauta de pesquisa, realçam-na, pois a incerteza em determinados aspectos do estudo linguístico histórico-comparativo, em vez de uma deficiência, é mais propriamente uma marca que corrobora uma práxis epistemológica fecunda.

Para findar esta seção e tendo como principal subsídio a proposta apontada por Lopes (2018) para a prefixação, apresentamos abaixo a esquematização de uma proposta de cotejo para a afixação em âmbito panromânico, que, com as devidas adaptações, poderia ser aplicada, sem maiores dificuldades, a 
um procedimento afixal específico (como a sufixação, por exemplo) ou mesmo a operações de composição:

Quadro 1 - Síntese do modus comparandi aplicado à afixação.

\begin{tabular}{|c|c|c|c|}
\hline \multicolumn{4}{|c|}{ - MODUS COMPARANDI - } \\
\hline \multicolumn{4}{|c|}{ Cotejo intralinguístico + Cotejo interlinguístico } \\
\hline \multicolumn{4}{|c|}{ A) Individual } \\
\hline SEMANTICAMENTE & $\begin{array}{l}\text { (i) quanto aos } \\
\text { sentidos que dado } \\
\text { afixo denota }^{10}\end{array}$ & \multirow{3}{*}{\multicolumn{2}{|c|}{$\begin{array}{c}\text { (ii) quanto aos esquemas } \\
\text { construcionais ou redes que dado afixc } \\
\text { molda }^{11}\end{array}$}} \\
\hline FORMALMENTE & $\begin{array}{c}\text { (i) quanto à } \\
\text { feição } \\
\text { etimológica ou } \\
\text { vernacular de } \\
\text { cada formativo e } \\
\text { quanto à sua rede } \\
\text { alomórfica e } \\
\text { alógrafa }\end{array}$ & & \\
\hline FUNCIONALMENTE & $\begin{array}{l}\text { (i) quanto à } \\
\text { seleção das } \\
\text { categorias das } \\
\text { bases por dado } \\
\text { afixo }\end{array}$ & & \\
\hline \multicolumn{4}{|c|}{ B) Geral } \\
\hline SEMANTICAMENTE & $\begin{array}{l}\text { (i) quanto ao } \\
\text { espectro } \\
\text { semântico geral } \\
\text { dos paradigmas } \\
\text { considerados }\end{array}$ & $\begin{array}{l}\text { (ii) quanto ao } \\
\text { fluxo de } \\
\text { conservação e } \\
\text { inovação nos } \\
\text { paradigmas } \\
\text { considerados }^{12}\end{array}$ & $\begin{array}{l}\text { (iii) quanto às } \\
\text { relações } \\
\text { morfossemânti } \\
\text { cas que os } \\
\text { paradigmas } \\
\text { considerados } \\
\text { engatilham }^{13}\end{array}$ \\
\hline FORMALMENTE & $\begin{array}{l}\text { (i) quanto à feição } \\
\text { mais conservadora } \\
\text { (etimológica) ou } \\
\text { mais inovadora } \\
\text { (vernacular) dos } \\
\text { paradigmas } \\
\text { considerados }\end{array}$ & \multicolumn{2}{|c|}{$\begin{array}{c}\text { (ii) quanto ao registro de } \\
\text { cognatos perfeitos e de } \\
\text { ausências de correspondências } \\
\text { entre um paradigma e os } \\
\text { demais }\end{array}$} \\
\hline
\end{tabular}

\footnotetext{
${ }^{10}$ Além da opacidade ou expletividade que porventura registrem.

${ }^{11} \mathrm{E}$ a produtividade e vitalidade de tais esquemas.

${ }^{12}$ A conservação sendo sinalizada pela manutenção de sentidos latinos e a inovação pelo surgimento de novos sentidos vernaculares, sobretudo através da metáfora, da metonímia e da perspectivação.

${ }^{13}$ A saber: polissemia, homomorfismo, sinmorfismo, antinomorfismo, intentando também verificar se os fluxos da polissemia de cada um dos afixos percorreram trajetórias semelhantes nos paradigmas abordados.
} 


\begin{tabular}{|l|c|c|}
\hline FUNCIONALMENTE & (i) quanto às & (ii) quanto ao surgimento (ou \\
& escolhas & não) de novos elementos, via \\
& divergentes de & gramaticalização (afixoides) nos \\
& prefixos para as & paradigmas considerados \\
& mesmas bases & \\
& lexicais no fluxo & \\
& histórico dos & \\
& paradigmas & \\
& considerados & \\
& & \\
\hline
\end{tabular}

Fonte: Elaboração própria, com base em Lopes (2018).

Pela proposta esquematizada no quadro acima, a colação entre as línguas abordadas se estabeleceria em dois domínios: o intralinguístico e o interlinguístico; e, dentro de cada um desses, sob uma ótica verticalizante (individual, particular) ou panorâmica (geral, horizontal). O cotejo intralinguístico consistiria na apreciação comparativa do comportamento (semântico, formal ou funcional) de dado procedimento morfolexical em cada um dos cortes sincrônicos considerados no interior de uma das línguas sob análise - e.g., para a prefixação na história do espanhol, o desempenho desse fenômeno no período medieval (1100 a 1500) versus no Siglo de Oro (1500-1700) versus na sincronia moderna (1700 a 1900) versus na sincronia contemporânea (1900 aos dias de hoje) -. Já o cotejo interlinguístico consistiria na colação entre fatos de língua (unidade morfológica, fenômeno morfossemântico etc.) pertencentes aos paradigmas morfolexicais de dois ou mais sistemas, como, e.g., o processamento do antinomorfismo (antonímia morfológica) em formativos e derivados do espanhol, do galego, do catalão, do asturiano e do português; ou o comportamento/desempenho formal, funcional e semântico dos prefixos intensificadores nessas línguas.

Por sua vez, o que vem denominado na tabela por cotejo individual nada mais seria que a comparação processada formativo a formativo. Por exemplo, no cotejo individual de corte intralinguístico, o prefixo re- da primeira sincronia do português arcaico versus o prefixo re- da segunda sincronia do português arcaico; no cotejo individual de corte interlinguístico, o prefixo reportuguês versus o prefixo re- castelhano. E, finalmente, por cotejo geral, entenda-se a comparação dos paradigmas morfolexicais entre duas ou mais línguas enfocadas, como, por exemplo, a constelação prefixal do português versus a constelação prefixal do galego versus a constelação prefixal do castelhano versus a constelação prefixal do catalão.

Se tomamos como base os dados compilados, descritos e analisados por Lopes (2018), é possível apresentar, como exemplificação, uma mostra da aplicação das linhas de cotejo intra e interlinguístico

\footnotetext{
${ }^{14}$ Por exemplo, esfriar (português) X enfriar (espanhol).

${ }^{15}$ Além dos afixoides, o aparecimento de outros elementos (e.g., pseudoafixos) e de outros fenômenos (e.g., lexicalização de afixos).
} 
a um elemento prefixal específico (sintetizadas na seção A do Quadro 1) ${ }^{16}$, que poderia ser o es-/ex- e que nos revelaria as seguintes informações:

\section{(i) ASPECTOS SEMÂNTICOS}

- Quanto aos sentidos que o afixo denota: no latim, a existência de sete valores semânticos: 'movimento para fora' (excurro), 'movimento para cima' (escendo), 'mudança de estado' (emollio), 'privação' (elinguis), 'intensificação' (exstimulo), 'perfectividade' (ebibo), cessativo (excōnsul), não sendo rara a sua adjunção como mero expletivo nessa língua (ementior, evincio); no período medieval, redução significativa dessa teia semântica no português e no castelhano, basicamente com a veiculação dos valores de 'privação, extração' (espulgar, esmalhar), além de um emprego muito recorrente como expletivo (escambhar, espaladinar, escomer, espartir, esprestar) e só esporadicamente a veiculação dos sentidos de 'movimento para fora' (estirar, escaminar) e 'mudança de estado' (escarzar, esfriar); a partir do período moderno, incidência apenas dos sentidos privativo-extrativo (esfornecinar, esgalhar) e, principalmente, do cessativo (exrector, ex-namorado), em ambas as línguas.

\section{(ii) ASPECTOS FORMAIS}

- Quanto à feição etimológica ou vernacular do formativo e quanto à sua rede alomórfica e alográfica: no latim, o prefixo constituía uma rede alomórfica tétrade, com as formas ex-, es-, e- e ef-; nas sincronias medievais, perde alguma força na alomorfia, embora apresente certa variabilidade alográfica, sendo detectadas no corpus as variantes es-/s- para o galegoportuguês, e es-/as- para o castelhano, com a preferência por uma maior feição vernacular para o prefixo, portanto; nas sincronias moderna e contemporânea, dá-se uma forte uniformização, com a seleção quase que exclusiva das variantes ex- e es-, sinalizando uma preferência pela feição etimológica (latina) da unidade prefixal.

\footnotetext{
${ }^{16}$ Uma mostra do cotejo geral entre os paradigmas prefixais do português e do castelhano em sua evolução histórica (contemplando todos os aspectos elencados na seção B do Quadro 1) seria demasiadamente extensa para constar de um artigo como este. Assim, remetemos o leitor à seção 6.2 e às Considerações Finais do estudo doutoral de Lopes (2018). Como rápida exemplificação, se tomássemos um único aspecto de ordem semântica (o fluxo de conservação e inovação de sentidos nos paradigmas considerados), teríamos os seguintes resultados: na maioria dos casos (como com os formantes $a d-, a b-, o b-$, pre-, $i n-$ e pro-), houve perda de matizes semânticos na travessia latim $\rightarrow$ romance; outra possibilidade nessa travessia é a de ganhos polissêmicos, a partir do surgimento de acepções inovadoras, concomitante à perda de sentidos da matriz etimológica, como ocorreu com o inter- e com o trans-; em outros casos (como com o ante, o in- lativo, o sobre- e o ambi-), uma situação de inalterabilidade em suas caracterizações semânticas no fluxo do latim ao romance; em alguns prefixos, como o re-, um contraste na sua polissemia quando comparadas as duas línguas românicas em questão (em sua passagem do período arcaico ao moderno-contemporâneo), com grande vitalidade de um valor intensificativo em castelhano, mas raramente detectado em derivados do português.
} 


\section{(iii) ASPECTOS FUNCIONAIS}

- Quanto à seleção das categorias das bases pelo afixo: no latim, a moldagem isocategorizadora de inúmeros verbos (excurro, escendo, exstimulo, evinco) e de alguns poucos nomes (exsanguis, edentulus, effertus); absoluta preferência pela geração isocategorial ou parassintética de verbos nas duas sincronias medievais do (galego-)português (escambhar, escavar, esmorecer) e do castelhano (escaminar, estajar, eslesiar), embora com a perda de alguma vitalidade (menor número de novos derivados) na segunda fase arcaica (sécs. XV-XVI); já nas fases moderna e contemporânea do português e do castelhano, uma nova guinada, com o declínio do emprego do formativo na geração homocategorial de novos verbos (mais no castelhano que no português) e o seu grande incremento na emergência de formas nominais, unicamente sob a variante $e x-$ (exministro, exprovincial, ex-marido, ex-diretor), num patente quadro de mudança funcional.

\section{(iv) ASPECTOS CONSTRUCIONAIS}

- Quanto aos esquemas construcionais ou redes que o afixo molda: existência de um esquema construcional para as formações verbais e outro para as nominais (dadas as particularidades formais, semânticas e funcionais que cada um desses dois grupos apresenta); ambos dotados de maior complexidade no latim (com diversas ramificações semânticas geradas mediante ativações metafóricas e metonímicas), dada a simplificação ocorrida na sua transformação românica, ao menos quanto ao português e ao castelhano; nova simplificação processada na passagem do período arcaico ao moderno-contemporâneo desses dois sistemas linguísticos vernaculares.

Como derradeira observação a respeito desse complexo esquema de comparação formalsemântico-funcional para a afixação, que se processa tanto em um eixo vertical quanto em um eixo horizontal, é conveniente ressaltar que parece ter como única exigência a consideração de um número robusto de dados empíricos, pois pode ser aplicado a dois sistemas linguísticos ou a um número maior deles; pode fundamentar-se em uma corrente específica dos estudos da linguagem ou em postulados de várias delas; pode, inclusive, selecionar apenas uma análise panorâmica (geral) em detrimento de uma análise atomística (individual) ou vice-versa. Dada tamanha flexibilidade, não seria temerário considerar que o modus comparandi delineado é um instrumental metodológico proveitoso ao desenvolvimento e avanço da análise de cunho histórico-comparativo atinente à formação de palavras, à lexicogênese de ordem morfológica. 


\section{Considerações finais}

A abordagem histórico-comparativa das línguas, embora para muitos pareça estar congelada no século XIX ou destituída de qualquer frescor para as práticas hodiernas de análise linguística, mostrase imersa em um processo de lenta e localizada revitalização, com o advento (ou alguma proliferação) de novas aplicações, seja a domínios ou níveis de língua anteriormente não privilegiados por esse paradigma científico (como a sintaxe e a formação de palavras), seja a outros anteriormente estudados, mas, desta feita, com a consideração das achegas de correntes linguísticas pós-comparativistas, do estruturalismo ao sociocognitivismo.

O estudo histórico-comparativo não necessariamente desemboca em si mesmo, ou seja, na comparação histórica pela comparação histórica (embora pensemos que a comparação per se já é algo digno de importância, pois permite saber um pouco melhor como de fato se comportam duas ou mais línguas cotejadas e até que ponto convergem e se singularizam e em quais aspectos tais convergências e dessemelhanças se manifestam), visto que pode servir, quando menos provisória e pontualmente, como meio de confirmação ou refutação de algumas questões gerais sobre as línguas sob colação. Com isso, parece-nos patente o valor heurístico e o potencial teórico da comparação entre línguas para a ciência linguística (MORENO CABRERA, 1997), pelo que nos coadunamos ao pensamento de Sánchez Miret (2008, p. 12-13), quando defende que “[...] el estudio comparativo nos coloca en disposición de hacernos preguntas que no se plantean en el estudio lengua por lengua y que, por lo tanto, ayudan a comprender mejor los fenómenos estudiados."

Neste artigo, além de repassarmos os principais expoentes da escola comparativista-histórica, seus postulados fundamentais e alguns estudos desenvolvidos sob suas pautas teórico-metodológicas, tivemos também como fim a exposição de uma proposta de cotejo historicocêntrico aplicável à lexicogênese, com a apreciação (em fluxo ascendente e descendente) de colações entre a forma originante (na matriz lexical latina) e as formas presentes nas línguas descendentes, que, mesmo sendo portadores de uma identificação histórica quanto à gênese (latina), podem não só apresentar divergências quanto à matriz, mas também entre si, devido ao fato de poderem gerar derivados ou formativos de certa forma alheios à matriz genolexical e alheios ao desenvolvimento históricodiacrônico de suas congêneres.

Cremos, com Bassetto (2005), Posner (1998) e Ridruejo (1989), que o método históricocomparativo, devidamente usado, permanece sendo profícuo, sobretudo para o conhecimento do léxico e da morfologia das línguas românicas, permitindo rastrear as confluências e singularidades que delas emergem, os encontros e desencontros que se dão no transcurso histórico-constitutivo desses sistemas idiomáticos. 


\section{Referências bibliográficas}

ÁLVAREZ DE MIRANDA, Pedro. Estar de vuelta sin haber ido: sobre la situación de los estudios léxicos en la lingüística histórica española. La corónica, Columbus, v. 34, n. 1, p. 131-135, 2005. Disponível em: http://www.lacoronica.org/dod/alvarez.pdf. Acesso em: 12 jan. 2018.

AREÁN-GARCÍA, Nilsa. Aspectos sincrônicos e diacrônicos do sufixo -ístico(a) no português e no galego. 2011. 835 f. Tese (Doutorado em Filologia e Língua Portuguesa) - Faculdade de Filosofia, Letras e Ciências Humanas, Universidade de São Paulo, São Paulo, 2011. Disponível em: https://teses.usp.br/teses/disponiveis/8/8142/tde-29082012-103453/pt-br.php. Acesso em: 8 jan. 2018.

AREÁN-GARCÍA, Nilsa. Estudo comparativo de aspectos semânticos do sufixo -ista no português e no galego. 2007. 463 f. Dissertação (Mestrado em Filologia e Língua Portuguesa) - Faculdade de Filosofia, Letras e Ciências Humanas, Universidade de São Paulo, São Paulo, 2007.

BANDELT, Hans-Jürgen. et al. Mitochondrial portraits of human populations. Genetics, v. 141, n. 2, p. 743-753, 1995. Disponível em: https://pubmed.ncbi.nlm.nih.gov/8647407/. Acesso em: 18 jul. 2020.

BANDELT, Hans-Jürgen, FORSTER, Peter; RÖHL, Arne. Median-joining networks for inferring intraspecific phylogenies. Molecular Biology and Evolution, v. 16, n. 1, p. 37-48, 1999. Disponível em: https://pubmed.ncbi.nlm.nih.gov/10331250/. Acesso em: 18 jul. 2020.

BARĐDAL, Jóhanna. Construction- Based Historical-Comparative Reconstruction. In: HOFFMANN, Thomas; TROUSDALE, Graeme (Ed.). The Oxford Handbook of Construction Grammar. Oxford: Oxford University Press, 2013. p. 438-457.

BASSETTO, Bruno Fregni. Elementos de filologia românica. 2. ed. São Paulo: EDUSP, 2005.

BRYANT, David; FILIMON, Flavia; GRAY, Russell D. Untangling our past: Languages, trees, splits and networks. In: MACE, Ruth; HOLDEN, Clare J.; SHENNAN, Stephen (Ed.). The evolution of cultural diversity: A phylogenetic approach. New York: Routledge, 2005. p. $67-84$.

BRYANT, David; MOULTON, Vincent. NeighborNet: an agglomerative algorithm for the construction of phylogenetic networks. Molecular Biology and Evolution, v. 21, n. 2, p. 255-265, 2004. Disponível em: https://academic.oup.com/mbe/article/21/2/255/1187993. Acesso em: 18 jul. 2020.

CALVET, Louis-Jean. Histoires de mots: étymologies européennes. Paris: Payot, 1993. 
CAMARGOS, Lidiane. Consolidando uma proposta de família linguística Boróro: contribuição aos estudos histórico-comparativos do tronco Macro-Jê. 2013. 232f. Tese (Doutorado em Linguística) - Instituto de Letras, Universidade de Brasília, Brasília. Disponível em: https://repositorio.unb.br/handle/10482/15116. Acesso em: 17 fev. 2018.

CAMPBELL, Lyle. Historical linguistics: an introduction. Cambridge (Massachusetts): The MIT Press, 1999.

COMPANY COMPANY, Concepción. Una paradoja de la lingüística histórica romance: el florecimiento de la sintaxis histórica románica. La corónica, Columbus, v. 34, n. 1, p. 144163, 2005. Disponível em: http://www.lacoronica.org/dod/company.pdf. Acesso em: 16 fev. 2018.

CONDÉ, Valéria. Estudo comparativo do sufixo -aria/-eria nas línguas ibero-românicas do Noroeste Peninsular. In: VIARO, Mário (Org.). Morfologia Histórica. São Paulo: Cortez, 2013. p. 106-117.

CROWLEY, Terry; BOWERN, Claire. An introduction to historical linguistics. 4. ed. New York: Oxford University Press, 2010.

CYRANKA, Lucia. Evolução dos estudos linguísticos. Práticas de Linguagem, Juiz de Fora, v. 4, n. 2, p. 160-198, jul./dez. 2014. Disponível em: http://www.ufjf.br/praticasdelinguagem/files/2014/09/160-198-Evolu\%C3\%A7\%C3\%A3odos-estudos-lingu\%C3\%ADsticos.pdf. Acesso em: 12 ago. 2017.

DÍAZ GARCÍA, María Teresa. Un modelo de diseño, análisis y explotación de un corpus: Sincronía y diacronía del sufijo castellano -oso. 2006. $1151 \mathrm{f}$. Tese (Doutoramento em Filología Románica) - Facultade de Filoloxía, Universidade de Santiago de Compostela, Santiago de Compostela, 2006.

DWORKIN, Steven. Further reflections on "Historical romance linguistics: the death of a discipline?”. La corónica, Columbus, v. 34, n. 1, p. 125-130, 2005. Disponível em: http://www.lacoronica.org/dod/dworkin.pdf. Acesso em: 23 fev. 2017.

DWORKIN, Steven. Thoughts on the future of a venerable and vital discipline. La corónica, Columbus, v. 31, n. 2, p. 9-17, 2003.

EYTHÓRSSON, Thórhallur; BARĐDAL, Jóhanna. Syntactic Reconstruction in Indo European: state of the art. Veleia: Revista de prehistoria, historia antigua, arqueología y filología clásicas, Vitoria-Gasteiz, n. 33, p. 83-102, 2016. Disponível em: https://addi.ehu.es/handle/10810/37313. Acesso em: 17 jul. 2020.

FARACO, Carlos Alberto. Lingüística histórica: uma introdução ao estudo da história das línguas. 2. ed. São Paulo: Parábola, 2005.

FARACO, Carlos Alberto. Estudos pré-saussurianos. In: MUSSALIM, Fernanda; BENTES, Anna Christina (Org.). Introdução à linguística: fundamentos epistemológicos. São Paulo: Cortez, 2004. p. 27-52. 
FRANÇOIS, Alexandre. Trees, Waves and Linkages: Models of Language Diversification. In: BOWERN, Claire; EVANS, Bethwyn (Ed.). The Routledge Handbook of Historical Linguistics. London: Routledge, 2014. p.161-189.

FREITAS, Érica. O tempo e o mento: história do sufixo latino -mentum e de seu desenvolvimento na língua portuguesa, em contraste com outras línguas românicas. 2014. 742 f. Tese (Doutorado em Letras) - Faculdade de Filosofia, Letras e Ciências Humanas, Universidade de São Paulo, São Paulo, 2014.

GARR, W. Randall. The Comparative Method in Semitic Linguistics. Aula Orientalis, Barcelona, v. 23, n. 1-2, p. 17-21, 2005.

GIRÓN, José Luis. Perspectivas de la lingüística histórica románica e hispánica. La corónica, Columbus, v. 34, n. 1, p. 176-189, 2005. Disponível em: http://www.lacoronica.org/dod/giron.pdf. Acesso em: 23 fev. 2017.

HARRISON, Shelly. On the limits of the comparative method. In: JOSEPH, Brian; JANDA, Richard (Ed.). The handbook of historical linguistics. Malden: Blackwell, 2005. p. 213243.

HASPELMATH, Martin. The geometry of grammatical meaning: Semantic maps and crosslinguistic comparison. In: TOMASELLO, Michael (Ed.). The new psychology of language: cognitive and functional approaches to language structure. Mahwah: Lawrence Erlbaum, 2003. p. 211-242. Vol. 2.

HEGGARTY, Paul; MAGUIRE, Warren; MCMAHON, April. Splits or waves? Trees or webs? How divergence measures and network analysis can unravel language histories. Philosophical Transactions of the Royal Society B, v. 365, p. 3829-3843, 2010. Disponível em: https://royalsocietypublishing.org/doi/pdf/10.1098/rstb.2010.0099. Acesso em: 19 jul. 2020.

HOLTUS, Günter; SÁNCHEZ MIRET, Fernando. Romanitas, filologia románica, romanística. Tübingen: Max Niemeyer Verlag, 2008.

HUSON, Daniel H.; BRYANT, David. Application of phylogenetic networks in evolutionary studies. Molecular Biology and Evolution, v. 23, n. 2, p. 254-267, 2006. Disponível em: https://academic.oup.com/mbe/article/23/2/254/1118872. Acesso em: 18 jul. 2020.

IORDAN, Iorgu. Introdução à linguística românica. Trad. de Júlia Ferreira. Lisboa: Calouste Gulbenkian, 1973 [1962].

JOSEPH, Brian D. The Comparative Method: simplicity + power = results. Veleia: Revista de prehistoria, historia antigua, arqueología y filología clásicas, Vitoria-Gasteiz, n. 33, p. 39-48, 2016. Disponível em: https://addi.ehu.es/handle/10810/37293. Acesso em: 16 jul. 2020. 
KABATEK, Johannes. Otra historia de las lenguas iberorrománicas: en torno a la actualidad de una vieja idea. In: HAFNER, Jochen; OESTERREICHER, Wulf (Org.). Mit Clio im Gespräch: Romanische Sprachgeschichten und Sprachgeschichtsschreibung. Tübingen: Gunter Narr Verlag, 2007. p. 173-194. Disponível em: https://publikationen.unituebingen.de/xmlui/handle/10900/46373. Acesso em: 16 fev. 2017.

KALYAN, Siva; FRANÇOIS, Alexandre; HAMMARSTRÖM, Harald (Ed.). Understanding language genealogy: alternatives to the tree model. Journal of Historical Linguistics, v. 9, n. 1 (especial), 2019. 176 p.

KESSLER, Brett. The mathematical assessment of long-range linguistic relationships. Language and Linguistics Compass, v. 2, n. 5, p. 821-839, 2008.

KILBURY, James; BONTCHEVA, Katina. Historical-comparative reconstruction and multilingual lexica. Proceedings of the Papillon 2004 Workshop on Multilingual Lexical Databases. Grenoble: s.n., 2004. p. 1-10.

KLEE, Carol; LYNCH, Andrew. El español en contacto con otras lenguas. Washington: Georgetown University Press, 2009.

LEHMANN, Winfred. Historical Linguistics: an introduction. New York: Holt, Rinehart and Winston, 1962.

LINDNER, Thomas. Word-formation in historical-comparative grammar. In: MÜLLER, Petter $e t$ al. Word-formation: an international handbook of the languages of Europe. Berlin: De Gruyter Mouton, 2015. p. 38-51.

LINHARES, Allan. Gramática histórico-comparativa: contribuições para a formação de línguas modernas. VERBUM, São Paulo, n. 7, p. 34-46, 2015. Disponível em: https://revistas.pucsp.br/verbum/article/view/22647. Acesso em: 21 fev. 2017.

LOPES, Mailson dos Santos. Estudo histórico-comparativo da prefixação no galego português e no castelhano arcaicos (séculos XIII a XVI): aspectos morfolexicais, semânticos e etimológicos. 2018. 2430 f. Tese (Doutorado em Língua e Cultura; Doutoramento em Linguística do Português) - Instituto de Letras/Faculdade de Letras, Universidade Federal da Bahia/Universidade de Coimbra, Salvador/Coimbra, 2018. Disponível em: https://repositorio.ufba.br/ri/handle/ri/29879. Acesso em: 3 set. 2019.

LÓPEZ-VIÑAS, Xoán. A formación de palabras no galego medieval: a afixación. 2012. 597 f. Tese (Doutorado em Filologia) - Facultade de Filoloxía, Universidade da Coruña, A Coruña, 2012. Disponível em: https://ruc.udc.es/dspace/handle/2183/10079?locale-attribute=es. Acesso em: 6 out. 2019.

LÜDTKE, Jens. La formación de palabras en las lenguas románicas: su semántica en diacronía y sincronía. Trad. de Elisabeth Beniers. México, D.F.: El Colegio de México, 2011. 
LÜDTKE, Jens. Gemeinromanische Tendenzen IV: Wortbildungslehre. In: HOLTUS, Günter; METZELTIN, Michael; SCHMITT, Christian. (Hrsg.). Lexikon der Romanistischen Linguistik. Tübinger: Niemeyer, 1996. p. 235-272.

MAÍLLO SALGADO, Felipe. Los arabismos del castellano en la Baja Edad Media: consideraciones históricas y filológicas. 3. ed. Salamanca: Ediciones Universidad de Salamanca, 1998.

MAKAEV, Ènver. Les rapports entre grammaire comparée, grammaire contrastive et grammaire typologique. Langages, Paris, ano 4, n. 15, p. 32-42, 1969. Disponível em: https://www.persee.fr/doc/lgge_0458-726x_1969_num_4_15_2516. Acesso em: 6 out. 2019.

MARTELOTTA, Mário Eduardo. Conceitos de gramática. In: MARTELOTTA, Mário Eduardo et al. (Org.). Manual de linguística. 2. ed. São Paulo: Contexto, 2012.

MATTOS E SILVA, Rosa Virgínia. O português arcaico: uma aproximação. Lisboa: IN-CM, 2008.

MAURER JR., Theodoro. Lingüística histórica. Alfa, Araraquara, v. 11, p. 19-42, 1967. Disponível em: https://periodicos.fclar.unesp.br/alfa/article/view/3297. Acesso em: 10 mar. 2017.

MAURER JR., Theodoro. A unidade da România Ocidental. São Paulo: Universidade de São Paulo, 1951.

MCMAHON, April; MCMAHON, Robert. Finding families: quantitative methods in language classification. Transactions of the Philological Society, London, v. 101, n. 1, p. 7-55, 2003.

MELLO, Antonio. Estudo histórico da família linguística Tupi-Guarani: aspectos fonológicos e lexicais. 2000. 286 f. Tese (Doutorado em Linguística) - Instituto de Comunicação e Expressão, Universidade Federal de Santa Catarina, Florianópolis, 2000. Disponível em: https://repositorio.ufsc.br/bitstream/handle/123456789/78560/170082.pdf?sequence=1. Acesso em: 10 mar. 2017.

MILLAR, Robert McColl (Ed.); TRASK, Larry. Trask's Historical Linguistics. 3. ed. Abingdon: Routledge, 2015.

MONZÓ GALLO, Carlos. Nariz, oreja y ojo en las lenguas románicas. CONGRESO INTERNACIONAL DE LINGÜÍSTICA Y DE FILOLOGÍA ROMÁNICAS, 26., 2010. Valencia, Actas... València: Gruyter. 2013. p. 303-314.

MUNTEANU COLÁN, Dan. Breve historia de la lingüística románica. Madrid: Arco/Libros, 2005.

MUÑOZ, Mirta. El método histórico-comparativo. Documentos Lingüísticos y Literarios, Valdivia, n. 2, p. 30-34, 1978. Disponível em: http://www.humanidades.uach.cl/documentos_linguisticos/document.php?id=132. Acesso em: 12 mar. 2017.

NASCENTES, Antenor. Elementos de filologia românica. Rio de Janeiro: Botelho, 2009 [1954]. 
NASCENTES, Antenor. A filologia românica no Brasil. Letras, Curitiba, v. 12, p. 36-42, 1961.

NICHOLS, Johanna; WARNOW, Tandy. Tutorial on Computational Linguistic Phylogeny. Language and Linguistics Compass, v. 2, n. 5, p. 760-820, 2008. Disponível em: http://bbe.univ-lyon1.fr/projets/tannier/ENSL/warnow_linguistics.pdf. Acesso em: 21 jul. 2020.

PAIXÃO DE SOUZA, Maria Clara. Linguística histórica. In: PFEIFFER, Claudia; NUNES, José Horta (Org.). Introdução às ciências da linguagem: língua, sociedade e conhecimento. Campinas: Pontes, 2006. p. 11-48.

PEDERSEN, Holger.Türkische Lautgesetze. Zeitschrift der Deutschen Morgenländischen Gesellschaft, Berlin, n. 57, p. 535-561, 1903.

POSNER, Rebecca. Las lenguas romances. Trad. de Silvia Iglesias. Madrid: Cátedra, 1998.

POTTIER, Bernard. Systématique des éléments de relation: étude de morphosyntaxe structurale romane. Paris: Klincksieck, 1962.

RAMA, Kasicheyanula. Computational methods for historical linguistics. 2009. $74 \mathrm{f}$. Tese (Masters in Technology in Computational Linguistics) - Department of Computer Science and Engineering, International Institute of Information Technology, Hyderabad, 2009. Disponível em: http://spraakdata.gu.se/taraka/CogID.pdf. Acesso em: 3 jan. 2017.

RAMIREZ, Henri. Línguas Arawak da Amazônia Setentrional: comparação e descrição. Manaus: Editora de Universidade do Amazonas, 2001.

RAMOS REMEDIOS, Emiliana. Para una revisión de la documentación hispana hasta el siglo XIII: los Cartularios de Valpuesta. In: PERDIGUERO VILLARREAL, Hermógenes (Ed.). Lengua romance en textos latinos de la Edad Media: sobre los orígenes del castellano escrito. Burgos: Universidad de Burgos; Instituto Castellano y Leonés de la Lengua, 2003. p. 243-262.

RANKIN, Robert. The comparative method. In: JOSEPH, Brian; JANDA, Richard (Ed.). The handbook of historical linguistics. Malden: Blackwell, 2005. p. 183-212.

RATCLIFFE, Robert. Afroasiatic comparative lexica: implications for long (and medium) range language comparison. In: HAJICOVÁ, E.; KOTESOVCOVÁ, A.; MIROVSKY, J. (Ed.). Proceedings of the Seventeenth International Congress of Linguists. 2003. p. 1-24. Disponível em: http://www.tufs.ac.jp/ts/personal/ratcliffe/comp\%20\&\%20methodRatcliffe.pdf. Acesso em: 8 ago. 2016.

RENZI, Lorenzo. Introducción a la filología románica. Trad. de Pilar García Mouton. Madrid: Gredos, 1982 [1976].

RIDRUEJO, Emilio. Viejos y nuevos problemas de la lingüística románica. La corónica, Columbus, v. 34, n. 1, p. 229-242, 2005. Disponível em: http://www.lacoronica.org/dod/ridruejo.pdf.

Acesso em: 16 mar. 2017. 
RIDRUEJO, Emilio. Las estructuras gramaticales desde el punto de vista histórico. Madrid: Síntesis, 1989.

RINGE, Don; WARNOW, Tandy; TAYLOR, Ann. Indo-European and computational cladistics. Transactions of the philological society, London, v. 100, n. 1, p. 59-129, 2002.

RIO-TORTO, Graça Maria. Operações e paradigmas genolexicais do português. Filologia e Lingüística Portuguesa, São Paulo, n. 2, p. 39-60, 1998. Disponível em: http://www.revistas.usp.br/flp/article/view/59658. Acesso em: 17 jul. 2020.

SÁNCHEZ MIRET, Fernando. Los complejos de la romanística y sus consecuencias para la investigación. Revue de linguistique romane, Paris, n. 285-286, p. 5-23, 2008.

SÁNCHEZ MIRET, Fernando. Proyecto de gramática histórica y comparada de las lenguas romances. München: LINCOM Europa, 2001.

SANTOS, Alice. Morfologia em diacronia - os caminhos e desvios de um afixo na história da língua: o percurso histórico-semântico do prefixo des- em bases sufixadas e em formações parassintéticas. 2016. 318 f. Tese (Doutorado em Filologia e Língua Portuguesa) - Faculdade de Filosofia, Letras e Ciências Humanas, Universidade de São Paulo, São Paulo, 2016.

Disponível em: https://www.teses.usp.br/teses/disponiveis/8/8142/tde-10052016-115122/ptbr.php. Acesso em: 16 mar. 2017.

SANTOS, Antonia Vieira dos. Compostos sintagmáticos nominais VN, NN, NA, AN e NPrepN no português arcaico (sécs. XIII-XV). 2009. 284 f. Tese (Doutorado em Letras e Linguística) - Instituto de Letras, Universidade Federal da Bahia, Salvador, 2009. Disponível em: https://repositorio.ufba.br/ri/handle/ri/11221. Acesso em: 22 jul. 2019.

SIMÕES NETO, Natival. O esquema X-ARI- do latim às línguas românicas: um estudo comparativo, cognitivo e construcional. 2020. 4297 p. Tese (Doutorado em Língua e Cultura) - Instituto de Letras, Universidade Federal da Bahia, Salvador, 2020. Disponível em: https://repositorio.ufba.br/ri/handle/ri/32014. Acesso em: 22 jul. 2020.

SIMÕES NETO, Natival. Um enfoque construcional sobre as formas $X$-eir-: da origem latina ao português arcaico. 2016. 655 p. Dissertação (Mestrado em Língua e Cultura) - Instituto de Letras, Universidade Federal da Bahia, Salvador, 2016. Disponível em: https://repositorio.ufba.br/ri/handle/ri/30404. Acesso em: 15 ago. 2019.

SOARES, Marília; CARVALHO, Fernando. As hipóteses de Aryon Rodrigues: validade, valor e papel no cenário dos estudos de línguas indígenas e de linguística histórica. D.E.L.T.A., São Paulo, v. 30, n. especial, p. 543-570, 2014. Disponível em: https://www.scielo.br/pdf/delta/v30nspe/0102-4450-delta-30-spe-0543.pdf. Acesso em: 22 mar. 2017.

SOLEDADE, Juliana. Semântica morfolexical: contribuições para a descrição do paradigma sufixal do português arcaico. 2004. 575 f. Tese (Doutorado em Letras e Linguística) - Instituto de Letras, Universidade Federal da Bahia, Salvador, 2004. 
STAROSTIN, Sergei. Lexicostatistics as a basis for language classification: increasing the pros, reducing the cons. In: FANGERAU, Heiner et al. (Ed). Classification and evolution in biology, linguistics and the history of science. Stuttgart: Franz Steiner Verlag, 2013. p. 125-146.

STAROSTIN, Sergei. Preliminary lexicostatistics as a basis for language classification: a new approach. Journal of Language Relationship, Moscou, v. 3, p. 79-116, 2010.

STAROSTIN, Sergei. Comparative-historical linguistics and lexicostatistics. In: COLIN, Renfrew; MCMAHON, April; TRASK, Larry (Ed.). Time Depth in Historical Linguistics.

Cambridge: The McDonald Institute for Archaeological Research, 2000. p. 223-265.

STOLOVA, Natalya. Where can working in tandem take us? Romance data meets grammaticalization theory. La corónica, Columbus, v. 34, n. 1, p. 243-252, 2005. Disponível em: http://www.lacoronica.org/dod/stolova.pdf. Acesso em: 22 mar. 2017.

TAGLIAVINI, Carlo. Orígenes de las lenguas neolatinas: introducción a la filología romance. Trad. de Juan Almela. Ciudad de México: Fondo de Cultura Económica, 1973 [1949].

TEJERO BENÉITEZ, Aurora. Perífrasis verbales: comparación de las perífrasis latinas con algunas lenguas romances. Hápax, Salamanca, n. 5, p. 65-83, 2012. Disponível em: http://www.revistahapax.es/V/Hpx5_Art5.pdf. Acesso em: 23 mar. 2017.

TRASK, Larry. Historical linguistics. Oxford: Oxford University Press, 1996.

VIARO, Mário. Uma breve história da Etimologia. Filologia e Linguística Portuguesa, São Paulo, v. 15, n. especial, p. 27-67, dez. 2013. Disponível em: http://www.revistas.usp.br/flp/article/view/82818. Acesso em: 23 mar. 2017.

VIARO, Mário. Etimologia. São Paulo: Contexto, 2011.

VIDOS, Benedek. Manual de linguística românica. Trad. de José Pereira da Silva. Rio de Janeiro: EDUERJ, 1996 [1956].

WALKDEN, George. The comparative method in syntactic reconstruction. 2009. $71 \mathrm{f}$. Thesis (MPhil in Linguistics) - University of Cambridge, Cambridge, 2009.

WRIGHT, Roger. Instrumentos nuevos: la sociolingüística del monolingüismo. In: CONGRESSO INTERNAZIONALE DI LINGÜÍSTICA E FILOLOGIA ROMANZA, 21., 1995, Palermo. Atti... Tübingen: Max Niemeyer Verlag, 1998. p. 483-486. 